\title{
Infection by endoparasites reduces maximum swimming speed of European smelt Osmerus eperlanus and European eel Anguilla anguilla
}

\author{
G. Sprengel, H. Lüchtenberg \\ Institut für Meereskunde, Abteilung Fischereibiologie, Düsternbrooker Weg 20, W-2300 Kiel 1, Germany
}

\begin{abstract}
Maximum swimming speed of European smelt Osmerus eperlanus and European eel Anguilla anguilla from the Elbe estuary was investigated in a circular experimental tank in relation to infection with 3 parasite species: the muscle parasites Pseudoterranova decipiens (Nematoda) and Pleistophora ladogensis (Microspora), both in smelt, and Anguillicola crassus, a parasite of the swim bladder in eel, were considered. All 3 parasites reduced the swimming performance of their hosts significantly. Smelt were seriously affected by double infection with $P$. decipiens and $P$. ladogensis. The reduction in maximum swimming speed of heavily infected fish was $32.2 \%$ in smelt and $18.6 \%$ in eel compared with uninfected fish. The reduced swimming ability of parasitized fish is assumed to make them more susceptible to predators and to entrainment by the cooling-water intakes of power plants than are uninfected fish, and it may reduce their ability to migrate. Especially in eel, which must migrate extensively to spawn, the possible effect of parasitization on population level has to be considered.
\end{abstract}

\section{INTRODUCTION}

Population dynamics of fish in the lower Elbe River, Germany, have been the subject of extensive surveys carried out during the last decade (Möller 1984, 1988). Diseases and condition of fish were studied by Anders (1988) and Möller (1990). It has been suspected that the large number of fish trapped at the inlet screens of the nuclear power plant at Brunsbüttel is partly caused by the high parasitization of the local fish stocks (Möller et al. 1989).

The aim of the present study was to determine maximum swimming speeds of the 2 most important fish species subject to this problem, eel Anguilla anguilla and smelt Osmerus eperlanus, by comparing parasitefree with parasitized fish. Smelt was found to be the most abundant species at the inlet screens, while eel was the most commercially valuable species.

About 49 to $71 \%$ of the local eel population is infected with Anguillicola crassus (Möller et al. in press), a nematode recently introduced from eastern Asia (Taraschewski et al. 1987). Adult A. crassus occur as large dark nematodes in the swim bladder of eel. They use small crustaceans as first intermediate hosts (De Charleroy et al. 1990).
Within the 11 to $18 \mathrm{~cm}$ groups of smelt, 36 to $69 \%$ were found to be infected by Pseudoterranova decipiens (Möller \& Klatt 1990) and 2.1 to $9.6 \%$ by Pleistophora ladogensis (Costa 1987). P. decipiens are present as L-III larvae coiled in the dorsal and caudal muscles of smelt. Adults occur in seals; small crustaceans serve as first intermediate hosts.

Pleistophora ladogensis occur as small, spindleshaped, whitish cysts (pansporoblasts) in the musculature and can be detected by small streaks of destroyed dermis along the lateral line. Their life cycle is unknown.

\section{MATERIALS AND METHODS}

Smelt between 5 and $17 \mathrm{~cm}$ length and eel between 17 and $45 \mathrm{~cm}$ length were collected from the water intake screens of the power plant at Brunsbüttel in the Elbe estuary, Germany. Water temperature was 15 to $18^{\circ} \mathrm{C}$, and salinity varied between 9 and $15 \%$. The fish were transported to the Institut für Meereskunde, Kiel, and adapted for 12 to $36 \mathrm{~h}$ in aerated aquaria at $17^{\circ} \mathrm{C}$ and $15 \%$ salinity before their swimming performance was studied. For the experiment, 249 smelt and 161 eel 


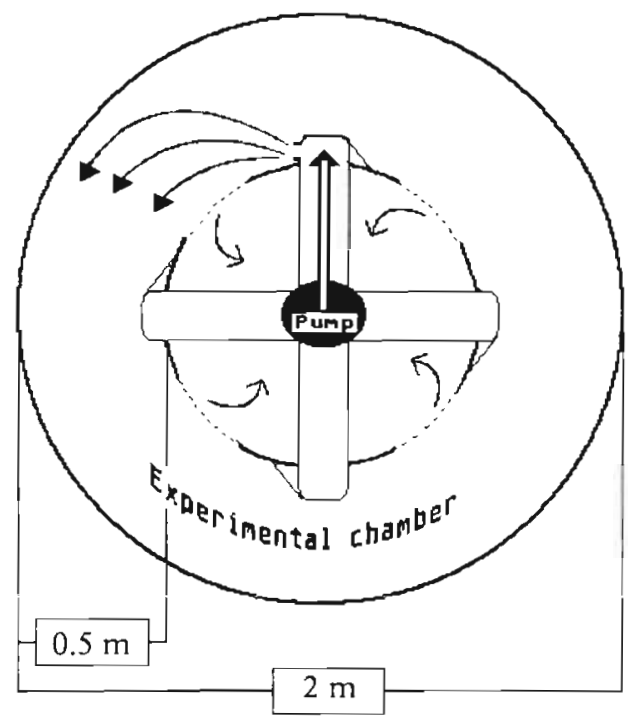

Fig. 1 Diagrammatic view of the tank from above, showing the direction of water flow (arrows), the water pump (center), and the water inlet

without external damage were selected.

In a circular channel, outer diameter $200 \mathrm{~cm}$ and inner diameter $50 \mathrm{~cm}$ (Fig. 1), a current was provided by an electric pump forcing water through jet pipes. Current speed could be increased up to $1.1 \mathrm{~m} \mathrm{~s}^{-1}$ and was continuously monitored by a flowmeter (measurement by propeller blade). During each test the current was steadily increased in increments of about $0.2 \mathrm{~m} \mathrm{~s}^{-1}$ to a velocity at which the fish could no longer maintain their position. The flowmeter reading at this moment was defined as maximum swimming speed. Trials lasted 2 to $3 \mathrm{~min}$. Immediately after the experiment muscle tissue of the smelt and swim bladders of the eel were examined for parasites.

Smelt were grouped according to their parasitological condition into 4 categories: (1) no muscle parasites, (2) Pseudoterranova decipiens only, (3) Pleistophora ladogensis only, (4) both parasitic species. Additionally, the intensity of infection (number of parasites per infested fish) and the length of $P$. decipiens were recorded.

To eliminate the effect of differences in length, the maximum swimming speed was standardized to a body

Table 1 Osmerus eperlanus and Anguilla anguilla. Relationship between maxinulum swimming speed $(v)$ and body length (l) of uninfected smelt and eel

\begin{tabular}{lccc|}
\hline Species & $\begin{array}{l}\text { No. of fish } \\
\text { examined }\end{array}$ & Function & $r$ \\
\hline Smelt & 90 & $v(I)=-0.16+0.24 \times \ln (I)$ & 0.79 \\
Eel & 69 & $v(l)=-0.82+0.45 \times \ln (I)$ & 0.98 \\
\hline
\end{tabular}

length of $15 \mathrm{~cm}$ for smelt and $32 \mathrm{~cm}$ for eel. A correction. factor was calculated from regression of length against. the swimming speed of uninfected fish (Table 1).

Maximum swimming speed of parasitized fish and non-parasitized fish was compared. Reduction in swimming speed was plotted as a function of the parasitic species and intensity of infection.

\section{RESULTS}

Infection intensity increased from 1.0 Pseudoterranova decipiens in smelt between 7 and $10 \mathrm{~cm}$ long to 3.4 nematodes in smelt of $17 \mathrm{~cm}$. Mean length of $P$. decipiens increased from $11 \mathrm{~mm}$ in $7 \mathrm{~cm}$ long smelt up to $28 \mathrm{~mm}$ in $17 \mathrm{~cm}$ smelt. The increase seems to be a linear function $\left(\mathrm{r}^{2}=0.86\right)$. Similar observations have previously been made by Möller \& Klatt (1990).

The maximum swimming speed of uninfected smelt and eel increased with body length. Table 1 shows logarithmic functions between speed and length. Infection by 3 or more nematodes seriously affected the maximum swimming speed of smelt, as shown in Fig. 2.

The maximum swimming speed of non-infected smelt of $15 \mathrm{~cm}$ standardized length was found to be $0.49 \mathrm{~m} \mathrm{~s}^{-1}$. The presence of 1 nematode reduced average swimming speed by $14.7 \%$, to $0.42 \mathrm{~m} \mathrm{~s}^{-1}$. More than 3 nematodes reduced average speed by $32.2 \%$, to $0.33 \mathrm{~m} \mathrm{~s}^{-1}$ (Table 2).

Infection with Pleistophora ladogensis on average caused a reduction in swimming speed of $19.3 \%$ in smelt (Table 3). The differences between light and heavy infection were not quantified.

The reduction in swimming speed of smelt infected by both parasite species (mean no. of nematodes 1.6) was $29.9 \%$. This is a much higher reduction than that

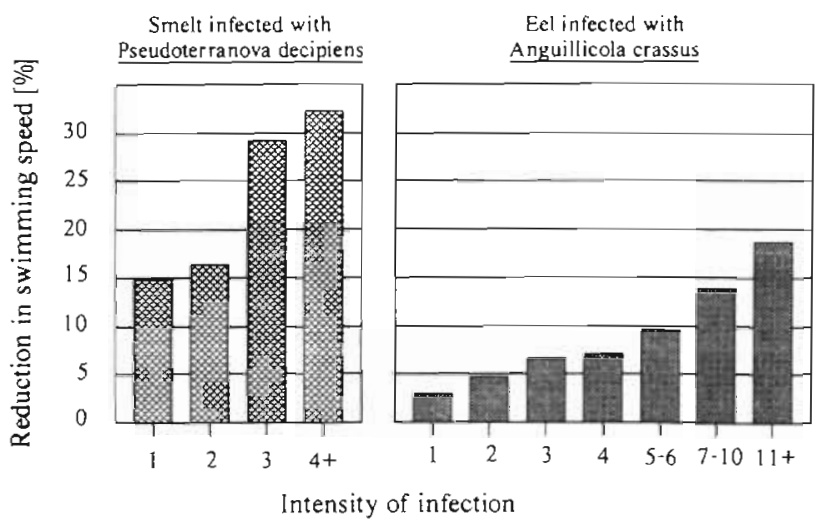

Fig. 2. Osmerus eperlanus and Anguilla anguilla. Percentage reduction in swimming speed of smelt and eel relative to intensity of infection with Pseudoterranova decipiens (in smelt) and Anguillicola crassus (in eell. Data calculated for $15 \mathrm{~cm}$ long smelt and $32 \mathrm{~cm}$ long eel 
Table 2. Osmerus eperlanus infected by Pseudoterranova decipiens. Swimming speed of European smelt, $15 \mathrm{~cm}$ standardized length, relative to intensity of infection with $P$. decipiens

\begin{tabular}{|cccc|}
\hline $\begin{array}{c}\text { P. decipiens } \\
(\mathrm{n})\end{array}$ & $\begin{array}{c}\text { Avg. speed } \\
\left(\mathrm{m} \mathrm{s}^{-1}\right)\end{array}$ & $\begin{array}{c}\text { Reduction in } \\
\text { speed }(\%)\end{array}$ & $\begin{array}{c}\text { No. of fish } \\
\text { examined }\end{array}$ \\
\hline 0 & 0.491 & - & 90 \\
1 & 0.419 & 14.7 & 54 \\
2 & 0.411 & 16.3 & 24 \\
3 & 0.348 & 29.1 & 10 \\
$4+$ & 0.333 & 32.2 & 12 \\
\hline
\end{tabular}

in smelt infected by 2 nematodes only or by microsporidians only (Fig. 3, Table 3).

Anguillicola crassus in the swim bladder of eel reduced swimming speed from $0.72 \mathrm{~m} \mathrm{~s}^{-1}$ in uninfected fish to $0.59 \mathrm{~m} \mathrm{~s}^{-1}$ in eel with more than 10 nematodes (Table 4). The reduction in speed relative to that of non-infected eel increased from $2.9 \%$ in eel infected with only 1 nematode to $18.6 \%$ in eel with more than 10 nematodes in the swim bladder (Fig. 2, Table 4).

Table 3. Osmerus eperlanus infected by Pleistophora ladogensis and Pseudoterranova decipiens. Swimming speed of European smelt, $15 \mathrm{~cm}$ standardized length, relative to infection by

2 muscle parasites. Intensity of infection: P. ladogensis, not quantified $_{i} P$. decipiens, 1.6

\begin{tabular}{|lccc|}
\hline Parasite species & $\begin{array}{c}\text { Avg. } \\
\text { speed } \\
\left(\mathrm{m} \mathrm{s}^{-1}\right)\end{array}$ & $\begin{array}{c}\text { Reduction } \\
\text { in speed } \\
(\%)\end{array}$ & $\begin{array}{c}\text { No. of } \\
\text { fish } \\
\text { examined }\end{array}$ \\
\hline Parasite-free & 0.491 & - & 90 \\
P. ladogensis & 0.396 & 19.3 & 19 \\
$P$. ladogensis and & 0.344 & 29.9 & 40 \\
$P$ P. decipiens & & & \\
\hline
\end{tabular}

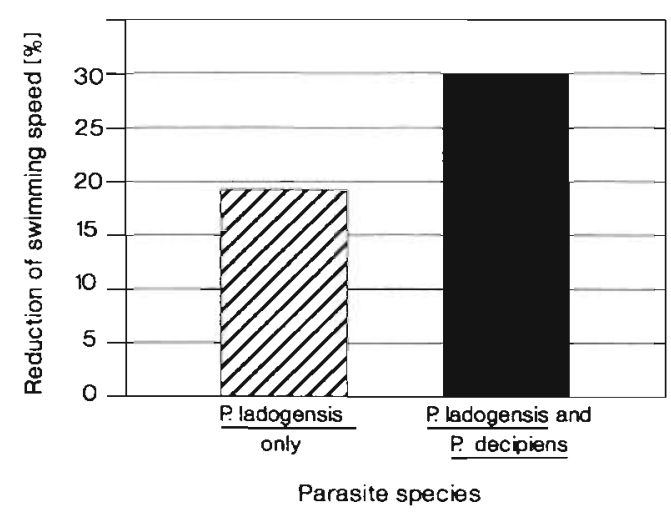

Fig. 3. Osmerus eperlanus infected by Pleistophora ladogensis and Pseudoterranova decipiens. Percentage reduction in swimming speed of smelt relative to parasite species. Data calculated for $15 \mathrm{~cm}$ long smelt. Mean intensity of infection: $P$. ladogensis, not quantified; $P$. decipiens, 1.6
Table 4. Anguilla anguilla infected by Anguillicola crassus. Swimming speed of European eel, $32 \mathrm{~cm}$ standardized length, relative to intensity of infection with $A$. crassus

\begin{tabular}{|cccc|}
\hline $\begin{array}{c}\text { A. crassus } \\
(\mathrm{n})\end{array}$ & $\begin{array}{c}\text { Avg. speed } \\
\left(\mathrm{m} \mathrm{s}^{-1}\right)\end{array}$ & $\begin{array}{c}\text { Reduction in } \\
\text { speed }(\%)\end{array}$ & $\begin{array}{c}\text { No. of fish } \\
\text { examined }\end{array}$ \\
\hline 0 & 0.725 & - & 69 \\
1 & 0.704 & 2.9 & 23 \\
2 & 0.691 & 4.7 & 16 \\
3 & 0.676 & 6.7 & 14 \\
4 & 0.674 & 7.0 & 9 \\
$5-6$ & 0.655 & 9.6 & 10 \\
$7-10$ & 0.624 & 13.9 & 14 \\
$11+$ & 0.590 & 18.6 & 6 \\
\hline
\end{tabular}

\section{DISCUSSION}

Information on the swimming speed of different fish species has been summarized by Webb (1975). It is common sense that swimming speed is closely related to body length of fish. This could also be demonstrated for uninfected smelt and eel from the Elbe estuary. In order to compare fish of different length groups without eliminating too much data, a mathematical transformation to standardized body length was used. It is assumed that infected fish exhibit the same relation between length and swimming speed, although this has not yet been proved and might be a source of error.

Webb (1975) indicated that prolonged activities in general are dependent on continuous functioning of the oxygen supply system and on removal of metabolic waste products. Any factor interrupting or affecting these systems, as well as those affecting the propulsion system itself, would affect swimming performance. Certain parasites are assumed to constitute such a factor.

The appearance of dead fish suggested that the parasites studied here might have serious effects on their hosts. Costa (1987) has demonstrated this with histopathological studies on Pleistophora ladogensis. In this case, the muscle fiber cells of hosts were destroyed and replaced by inflamed tissue or by pansporoblasts containing sporoblasts or mature spores. Kahl (1938a, b) described inflammation of the muscle tissue due to movements of nematodes. Möller \& Anders (1986) reported that smelt older than 2 yr displayed a significant reduction of 11 to $14 \%$ in condition factor due to infestation with Pseudoterranova decipiens.

For both Pseudoterranova decipiens and Pleistophora ladogensis the intensity of infection increases with length of the host (Costa 1987, Möller \& Klatt 1990). Arthur et al. (1982) concluded that in general most larval or cyst-producing parasites infecting marine fishes may be accumulated with increased age, 
given that the host is exposed to infective stages throughout its life history'. It is reasonable to assume that reduction in swimming speed is higher in older fish due to their heavy load of parasites.

Although the relationship between host and parasite usually seems to be well balanced, infected fish become handicapped in the competition for feeding and become more susceptible to predation, including anthropogenic 'predation' by trawl fisheries and cooling-water intake.

Changes in animal behaviour due to parasitism support the transfer of the parasite from the intermediate to the predatory final host, through reduction of mobility and endurance of the intermediate host (Holmes \& Bethel 1972. Schaub 1989). In the case of Pseudoterranova decipiens this makes ecological sense. The final host of $P$. decipiens in the southeastern North Sea is the seal Phoca vitulina (Lick 1989). Part of the seal's diet is smelt (Behrends 1985), and it is reasonable to assume that smelt infected with nematodes are more easily caught by seals than are parasite-free fish.

Demonstration of pathological effects of Anguillicola crassus on eel has so far been restricted to histopathological findings and changes in blood composition. Boon et al. (1990) found decreased levels of plasma proteins and a lower haematocrit in heavily infected eels. In addition, Neumann (1985) observed a high feed-conversion factor associated with infection by $A$. crassus in cultured eel. Recent investigations (Stemmer 1988, Banning \& Haenen 1990) suggest that the health of eels can be impaired by large numbers of L-III A. crassus.

Our investigation demonstrates that even a small number of nematodes affects the host pathogenically. Considering that adult eel must migrate several thousand kilometers to spawn, it is reasonable to assume that fish affected by parasites are seriously handicapped and probably do not reach the spawning areas.

Our results also open to question the reliability of infection rates calculated from trawled fish. Hemmings (1973) observed that fishes in towed fishing gear try to keep station with the moving net and swim at the speed of the net until they are exhausted or escape. As parasitized fish swim more slowly, it is likely that fish infected with certain pathogens have less chance of escape and thus occur at higher prevalences in samples taken by trawling fishing gears than in the original population.

\section{LITERATURE CITED}

Anders, K. (1988). Biology of tumorous and tumor-like diseases of tishes from the Elbe River Verlag H. Möller, Kiel.
Arthur, J. R., Margolis, L., Whitaker, D. J., McDonald, T. E. (1982). A quantitative study of economically important parasites of walleye pollock (Theragra chalcogramma) from British Columbian waters and effects of postmortem handling on their abundance in the musculature Can. J. Fish. Aquat. Sci. 39: 710-726

Banning, P. van, Haenen, O. L. M. (1990). Effects of the swimbladder nematode Anguillicola crassus in wild and farmed eel, Anguilla anguilla. In: Perkins, F. O., Cheng, T C. (eds.) Pathology in marine science. Academic Press, New York, p. 317-330

Behrends, G. (1985). Zur Nahrungswahl von Seehunden (Phoca vitulina) im Wattenmeer Schleswig-Holsteins. Z. Jagdwiss. 31: 3-14

Boon, J. H., Cannaerts, V M. H., Augustijn, H., Machiels, M. A. M. De Charleroy, D., Ollevier, F. (1990). The effect of different infection levels with infective larvae of Anguillicola crassus on haematological parameters of European eel (Anguilla anguilla). Aquaculture, Amsterdam 87: 243-253

Costa, G. (1987). Eine Übersicht fischpathogener Mikrosporidien mit eigenen Untersuchungen am Stint. M.Sc. thesis, University of Kiel

De Charleroy, D., Grisez, L., Thomas, K., Belpaire, C., Ollevier, F. (1990). The life cycle of Anguillicola crassus. Dis. aquat. Org. 8: 77-84

Hernmings, C. C. (1973). Direct observation of the behaviour of fish in relation to fishing gear. Helgoländer wiss. Meeresunters. 24: 348-360

Holmes, J. C., Bethel, W. M. (1972). Modification of intermediate host behaviour by parasites. Zool. J. Linn. Soc. 51 (Suppl. 1): 123-149

Kahl, W. (1938a). Nematoden in Seefischen. I. Z. ParasitKde 10: 415

Kahl, W. (1938b). Nematoden in Seefischen. II. Z. ParasitKde 10: 513

Lick, R. (1989). Stomach nematodes of harbour seal (Phoca vitulina from the German and Danish Wadden Sea. In: Möller, H. (ed.) Nematode problems in North Atlantic fish. Comm. Meet. int Coun. Explor Sea C. M.-ICES/F: 6: 29

Möller, H. (1984). Daten zur Biologie der Elbfische. Verlag H. Möller, Kiel

Möller, H. (1988). Fischbestände und Fischkrankheiten in der Unterelbe 1984-1986. Verlag H. Möller, Kiel

Möller, H. (1990). Association between diseases of flounder (Platichthys flesus) and evironmental conditions in the Elbe Estuary, FRG. J. Cons. int. Explor. Mer 46: 187-199

Möller, H., Anders, K. (1986). Diseases and parasites of marine fishes. Verlag H Möller, Kiel

Möller, H, Holst, S., Lüchtenberg, H., Petersen, F. (1991). Infection of eel Anguilla anguilla from the River Elbe estuary with two nematodes, Anguillicola crassus and Pseudoterranova decipiens. Dis. aquat. Org. (in press)

Möller, H. Klatt, S. (1990). Smelt as host of the sealworm (Pseudoterranova decipiens) in the Elbe estuary. In: Bowen, W. D. (ed.) Population biology of sealworm (Pseudoterranova decipiens) in relation to its intermediate and seal hosts. Can. Bull. Fish. Aquat. Sci. 22: 129-138

Möller, H., Lüchtenberg, H., Schröder, S., Voigt, M. (1989). Untersuchungen zur Menge und Kondition der 1987/88 am Einlaufrechen des Kernkraftwerkes Brunsbüttel angefallenen Fische und Krebse. Unpublished manuscript, Kernkraftwerk Brunsbüttel GmbH, Germany

Neumann, W. (1985). Schwimmblasenparasit Anguillicola bei Aalen. Fischer und Teichwirt 11: 322

Schaub, G. A. (1989). Auswirkungen von Parasiten auf das Verhalten ihrer Wirte. Biol. unserer Zejt 6 (19): 196-202 
Stemmer, B. (1988). Untersuchungen der Larvalentwicklung von Anguillicola crassus (Nematoda: Dracunculoidea) in verschiedenen Zwischenwirten. M.Sc. thesis, Ruhr University, Bochum

Taraschewski, H., Moravec, F., Lamah, T., Anders, K. (1987). Distribution and morphology of two helminths recently

Responsible Subject Editor: W. Körting, Hannover, Germany introduced into European eel populations: Anguillicola crassus (Nematoda, Dracunculoidea) and Paratenuisentis ambiguus (Acanthocephala, Tenuisentidae). Dis. aquat. Org. 3: 167-176

Webb, P. W (1975). Hydrodynamics and energetics of fish propulsion. Bull. Fish. Res. Bd Can. 190: 1-158

Manuscript first received: January 9, 1991

Revised version accepted: April 23, 1991 